\title{
ГЛУШІННЯ ПРОГРАМ УКРАЇНСЬКИХ РЕДАКЦИЙ ЗАКОРДОННИХ РАДІОСТАНЦІЙ У ПЕРІОД «ХОЛОДНОЇ ВІЙНИ»
}

\author{
Іван Ципердюк \\ ПВНЗ «Університет Короля Данила», \\ вул. С. Коновальияя, 35, 76000, Івано-Франківськ, Україна, \\ e-mail:ivandjuk@ukr.net
}

У статті розглянуто особливості глушіння програм українських редакцій закордонних радіостанцій під час протистояння Радянського Союзу та Заходу у ХХ столітті. Показано, що радянські ідеологи надавали особливого значення радіовійні з радіостанціями «Свобода», «Голос Америки», Бі-Бі-Сі, «Німецька хвиля», радіо «Ватикан» та ін. Наголошено, що найінтенсивніші перешкоди в ефірі створювались передовсім для радіостанцій, які транслювали матеріали українських дисидентів.

Ключові слова: українські редакції закордонних радіостанцій, глушіння, холодна війна, дисиденти.

Для того щоб почути правдиву інформацію про стан справ у державі та світі, радянські громадяни налаштовували радіоприймачі на хвилі радіостанцій «Свобода», «Голос Америки», Бі-Бі-Сі, «Німецької хвилі» та ін. Увесь період «холодної війни» між Заходом та СРСР характеризувався нарощуванням потужностей радіостанцій вільного світу, які вели мовлення на територію Радянського Союзу та країн соціалістичного табору. У відповідь СРСР та його сателіти почали інтенсивно розбудовувати колосальну систему радіоперешкод, основною метою якої було завадити слухачам приймати програми «ворожих радіоголосів». У результаті побудова мережі глушіння програм закордонних радіостанцій обійшлася у велетенські суми, які, як наслідок, недотримували промисловість, сільське господарство, наука та культура. Однак політика ізоляції від демократичного світу в інформаційній сфері, яку здійснював Радянський Союз, позбавляючи власних громадян права на отримання та обмін інформацією, як це гарантувала відповідна резолюція Генеральної асамблеї ООН від 14 грудня 1950 року, цілком відповідала офіційному курсу держави, спрямованому на збереження будь-якою ціною влади КПРС: «Совєтське радіоглушіння було лютим, а досвідом в експлуатації такого устаткування просили поділитися також комуністичні керівництва у Східній Європі. «Голос Америки», Бі-Бі-Сі, «Радіо Свобода» та «Радіо Вільна Європа» не можна було почути на цих теренах упродовж багатьох років. Радіоприймачі перепроектовувалися для виключення можливості слухання небажаних короткохвильових частот» [1: 416]. Інформація, яка надходила із Заходу

(C) Ципердюк I., 2018 
через радіоефір, не лише руйнувала монополію офіційних радянських ЗМІ, але й висвітлювала найбільш непривабливі сторони радянської дійсності.

Побудова велетенської за своїми масштабами системи радіоперешкод, яку створив СРСР, не має аналогів в історії. Вивчення цієї проблеми постійно привертало увагу науковців. Різних її аспектів торкалися у своїх працях вчені-журналістикознавці: І. Мащенко, Ю. Каганов, О. Ремовська, О. Богуславський, І. Гель та ін. Литовський радіожурналіст та науковець Р. Плейкіс опублікував окреме дослідження, у якому детально аналізує особливості глушіння закордонних радіостанцій у СРСР, спираючись на численні факти та документи, які йому вдалося зібрати в 90 -х роках XX ст., перебуваючи на посаді міністра зв'язку Латвії. Однак ці дослідження вимагають узагальнення і з'ясування особливостей глушіння програм українських редакцій закордонних радіостанцій.

Мета нашого дослідження - проаналізувати специфіку глушіння програм українських редакцій закордонних радіостанцій, те, скільки коштів вкладалося в цей напрямок, а також причини особливої уваги радянських ідеологів до закордонного радіомовлення на Україну.

Першість у застосуванні радіоперешкод щодо сигналів радіостанцій ворожих країн належить Німеччині та Радянському Союзу. У 20-х роках XX ст. Німеччина «глушила» радіостанцію Комінтерну. СРСР розпочав глушіння «ворожих радіоголосів» 1931 року. Однак планово Радянський Союз почав використовувати глушіння як основний елемент протистояння в радіоефірі напередодні Другої світової війни: «Систематичне глушіння іноземних радіостанцій Радянський Союз розпочав, за різними даними, у 40-х роках: тоді під «гарячу руку» потрапило радіо «Ватикан». У те ж десятиліття СРСР записало собі у вороги ще й «Голос Америки» та «Бі-Бі-Сі». До середини XX століття Радянський Союз озброївся потужною системою радіозахисту: майже дві тисячі передавачів працювали на придушення «ворожого» сигналу 3-за кордону» [2: 23]. Глушіння разом із перехопленням та контрпропагандою стало одним із основних механізмів протидії закордонним радіостанціям.

Ведення радіовійни з боку Радянського Союзу було закономірним наслідком надзвичайних зусиль для встановлення тотального контролю над поширенням незалежної інформації. Слухачі СРСР прагнули ознайомитися з альтернативною офіційній позицією щодо подій у державі та за кордоном. Цьому сприяло також те, що закордонні радіостанції, як і належить масмедіа, миттєво реагували на поточні події: «Характеризуючи західне радіомовлення, слід вказати на його більшу інформативність у порівнянні з неоперативними та закритими радянськими ЗМІ, що давало першому значні переваги. Про масу подій радянські громадяни дізнавалися саме з західного радіо» [3: 60]. Натомість у СРСР та соціалістичних країнах-сателітах домінував кардинально інший підхід: «Для радянської влади відразу став проблематичним головний принцип функціонування радіо, як безперешкодного засобу поширення інформації, котрого не могли обмежити жодні політичні кордони, а відтак великі зусилля було спрямовано на те, щоб установити тотальний контроль над радіопростором і боротися із загрозами впливу ззовні» [4].

31948 року глушіння програм іноземних радіостанцій, яке здійснював Радянський Союз, повністю суперечило Загальній декларації прав людини, стаття 19 якої закріплювала право на свободу переконань і їхнє вільне волевиявлення. Це право передбачало, що «кожна людина має право на свободу переконань і на їх вільне вияв- 
лення; це право включає свободу безперешкодно дотримуватись своїх переконань та свободу шукати, одержувати і поширювати інформацію та ідеї будь-якими засобами і незалежно від державних кордонів» [5]. Як уже відзначалося, 1950 року ООН прийняла резолюцію (як рекомендаційний документ), у якій засудила практику глушіння. Однак це жодним чином не вплинуло на діяльність Радянського Союзу в цій сфеpi. Навіть навпаки - 19 січня 1961 року була прийнята постанова ЦК КПРС «Щодо заходів по посиленню боротьби з ворожою радіопропагандою», яка обгрунтувала значне зростання витрат на глушіння «ворожих радіоголосів».

У сфері особливої уваги радянських ідеологів цілком закономірно перебувала Україна через визвольні змагання та численні повстання 20-30-х років, боротьбу УПА в роки Другої світової та повоєнний час, рух шістдесятників, найбільшу кількість політв'язнів-українців у таборах та тюрмах. Трансляції програм українських редакцій закордонних радіостанцій у цьому контексті сприймалися як цілком ворожі, що підсилюють позиції дисидентів в УРСР, встановлюють зв'язок правозахисників із вільним світом. Завідувач ідеологічного відділу, а пізніше секретар ЦК КПУ Л. Кравчук так описував тодішню ситуацію в Україні: «По-перше, була розроблена ціла величезна система глушіння радіопередач, це робила радянська влада, партія, КДБ. Я знав цифри, я вже про них трохи забув, які ці цифри, але вклади у глушіння були набагато більші, ніж розвиток самої системи радіо і телебачення. Під Києвом були цілі гектари землі, зайняті глушильними системами, і пробитися через них було надзвичайно важко» [6].

Як свідчать сучасники, на хвилях радіо «Свобода», намагаючись допомогти аудиторії в СРСР прорватись через кордони радіоперешкод, постійно передавали схему створення власними руками спеціальної антени, яка допомогла б зменшити дію глушіння і дала змогу приймати програми «ворожих радіоголосів». Така інформація для слухачів у СРСР була не зайвою, бо лише в Україні діяли сотні глушилок: «Радіоцентри, технічні засоби яких здійснювали радіопротидію, були розташовані в містах: Дніпропетровськ, Донецьк, Київ, Львів, Одеса, Сімферополь, Ужгород, Харків, Чернівці. Всього по Україні працювало 307 передатчиків, у т. ч. по Києву 72» [7: 196]. Цю інформацію у порівнянні з іншими республіками СРСР наводить Р. Плейкіс: «У 80-ті роки в Литві з населенням 3,5 млн. осіб було 60 передавачів на 5-ти РВП (радіостанція встановлення перешкод. - I. Ц.), в Білорусії (10 млн.) - 90 передавачів, в Україні - більше 300 передавачів. В 1986 р. в СРСР було 13 потужних РВП дальнього радіозахисту (100-120 передавачів) і міські станції глушіння у 81 місті (приблизно 1200-1300 передавачів)» [8]. I це була далеко не межа. 1984 року вийшла постанова Політбюро ЦК КПРС й уряду СРСР про будівництво на Україні 18 комплексів радіоперешкод на 15-20 передавачів кожен. Їх повинні були ввести в дію до 1989 року, натомість до 1990 року вдалося збудувати лише три такі комплекси [9: 124].

Радянський Союз на глушіння програм радіостанцій «Свобода», «Голос Америки», Бі-Бі-Сі, «Німецької хвилі», радіо «Ватикан» та інших виділяв колосальні кошти: «За даними звітів ЦРУ США, наприкінці 60-х років щорічні витрати СРСР на глушіння і пов'язані з ним операції («успішні лише ситуативно») сягали близько 150 мільйонів доларів, тоді як загальний бюджет Радіо Вільна Свропа і Радіо Свобода у ті роки становив майже 35 мільйонів доларів» [2: 27]. Журналістикознавець I. Мащенко у своєму дослідженні про особливості функціонування тоталітарного 
ефіру підтверджує цю інформацію, відзначаючи, що значна частина коштів (майже тридцять відсотків), «які за радянських часів виділялися на розвиток і вдосконалення матеріально-технічної бази радіомовлення і телебачення в Україні, йшла, за висновком телевізійників, на «нагрівання ефіру», тобто на заглушування «ворожих радіоголосів» [9: 124]. Загалом лише впродовж 1971-1988 рр., за оцінками західних експертів, було витрачено 1 мільярд карбованців [8]. Ветеран радіостанції «Свобода» Джин Сосін стверджував, що 70\% глушіння з боку СРСР було скеровано на радіо «Вільна Європа» і радіо «Свобода». Незважаючи на такі неймовірні фінансові витрати, радянським ідеологам не вдавалося зупинити потік інформації, який поширювали радіостанції вільного світу. Усі в Радянській Україні (від робітників та селян до студентів та науковців), хто прагнув мати доступ до правди, слухали програми українських редакцій закордонних радіостанцій: «Професор, історик Ярослав Грицак пригадує, як у 70-х, ще студентом, йдучи дуже рано на потяг селом, можна було почути звуки радіостанції Радіо Свобода. Майже усі люди по селах слухали «ворожі голоси» у період «залізної завіси». Поки йшов, то міг послухати усі новини» [10]. Знаний український інтелектуал, дисидент Мирослав Маринович наголошує, що слухання «ворожих радіоголосів» в Україні, незважаючи на глушіння, формувало не лише його особисто та друзів-дисидентів, але й усе суспільство. Були цілком практичні результати від прослуховування програм українських редакцій закордонних радіостанцій. Учитель з Івано-Франківщини Василь Яківчик згадує: «Мене Свобода в 72-му році врятувала від арешту, тому що я працював у гімназії і дізнався, що у моїх товаришів був обшук у січні і я за той час, що до мене мали прийти, поховав усі матеріали. А мав їх дуже багато: Сверстюка «Собор в риштованні», «Котляревський сміється», i другі праці мав. А до мене з обшуком прийшли аж у березні, так що я до того часу був підготовлений» [6]. Підтвердженням того, що ефіри «ворожих радіоголосів» постійно слухали, незважаючи на всі радіоперешкоди, мешканці України, $\epsilon$ таємні документи КДБ, які нещодавно оприлюднив Центр досліджень визвольного руху. В одному з них ідеться про «оперативні заходи», до яких удався КДБ УРСР для виявлення анонімних авторів, що надіслали листи до української редакції радіо «Свобода», маючи надію, що там їх отримають. Бажання радянських спецслужб знайти невідомих адресантів стає зрозумілим, варто лише зацитувати уривок листа, який перехопили у Ворошиловградській (зараз Луганській) області: «Як ви гадаєте, що може зробити XXIV з'їзд, а я думаю, що для країни XXIV з'їзд зробить багато, для робітничого класу нічогісінько, може лише зробити для робітника в гірший бік» [11]. Це лише окремі приклади з численних спогадів і документів тих, хто слухав в УРСР програми українських редакцій закордонних радіостанцій.

Хоча глушіння програм українських редакцій закордонних радіостанцій не давало бажаного ефекту і завдавало економіці значних збитків, прослуховування ефіру та запис «ворожих програм» оператори в Радянській Україні вели цілодобово і в чотири зміни: «На високопрофесійній приймальній апаратурі оператор у Києві чи в іншому українському місті знаходив, наприклад, україномовну передачу станції «Радіо «Свобода», по системі прямого зв’язку давав команду вмикати радіопередавач-«глушилку» на конкретній частоті. В ефірі з'являлися шуми-перешкоди. Залежно від поточних подій і політичної обстановки в світі на пункт глушіння надходили «зверху» команди про те, які передачі «давити», а які не чіпати. Об’єктами номер 
один були програми радіостанцій «Свобода», «Голос Америки», Бі-Бі-Сі, «Голос Ізраїлю», «Німецька хвиля», «Голос Ватикану»...» [9: 122-123].

Варто також зауважити, що в періоди налагодження стосунків СРСР із Заходом глушіння ефірів закордонних радіостанцій тимчасово припинялося. Під час «холодної війни» це робилося двічі: з 19 червня 1963 року до 21 серпня 1968 року і з 10 вересня 1973 року до 20 серпня 1980 року. Радянський Союз у цей час припинив глушити програми «Голосу Америки», Бі-Бі-Сі та «Німецької хвилі». Усі ці радіостанції $є$ офіційними речниками своїх країн. Натомість потужності, які звільнилися в цей час, були переважно скеровані на глушіння програм радіо «Свобода», проти якого ніколи не припинялося глушіння, аж до його повного припинення 30 листопада 1988 року.

Мовлення українських редакцій закордонних радіостанцій на Україну завжди залишалось у центрі уваги радянських ідеологів та спецслужб. Феномен «шістдесятників», який отримав своє найбільше поширення в радянській Україні, спершу насторожив, а згодом і налякав тоталітарний режим. Послідовники «хрущовської відлиги» від закликів щодо відновлення соціалістичної законності та наповнення реальним змістом національних прав народів СРСР і українців зокрема дуже швидко прогресували в напрямку закликів та дій щодо відновлення фактичної самостійності України. Це викликало шалені репресії з боку радянського режиму. Але «оприлюднене на західному радіо подекуди змушувало радянську владу охолодити свій репресивний запал: «Жодна акція протесту - у тому числі страйки, тривалі голодування - не досягала позитивного результату, якщо протестувальників не підтримували закордонні організації чи зарубіжні політики, якщо про них не говорили закордонні радіостанції», - вважає Василь Овсієнко» [2: 42]. Українські редакції закордонних радіостанцій стали основним рупором українських «шістдесятників», i відповідно радіостанції, які передавали їхні заяви, відозви, звернення, твори, СРСР нещадно глушив. Питання надання права голосу дисидентам, зокрема українським, було настільки гострим, що воно окремо розглядалося під час засідання конференції 3 прав людини в канадському Торонто 29 листопада 1983 року на панелі «Політика радіотрансляції Заходу для блоку країн Сходу та їхня ефективність», де виступали представники радіо «Свобода», «Голос Америки», «Німецька хвиля» та ін. Для українців розгляд цього питання був особливо важливим, бо це означало, що світ укотре зверне свою увагу на те, що ціла нація фактично позбавлена голосу [12: 94-95].

Ведення радіовійни з боку СРСР проти Заходу стало закономірним наслідком політики ізоляції власних громадян від зовнішнього світу, зокрема від інформації, яка надходила з іншого боку «залізної завіси». Урешті життя в Радянському Союзі перетворилось на повний фарс, і щоб не виникало жодних сумнівів, необхідно було повністю позбавити населення доступу до джерел, які б підривали довіру до правильності курсу, який декларувала КПРС: «Прагнення творити реальність зробило 3 радянського життя якийсь маскарад. Важливою стала не правда, а те, що можна було видати за правду, тож структуру фактичної реальності було замінено організованою фальсифікацією, щоби реальне життя могло (хай і постфактум) виглядати відповідним радянській ідеології» [13: 38].

В Україні, де дисидентський рух набрав найбільшого в СРСР розмаху та сили, незважаючи на систематичне глушіння, заборонені радянською цензурою твори та відозви в'язнів сумління за посередництва українських редакцій закордонних раді- 
останцій ставали доступними широкому колу слухачів. Радянська система, за словами правозахисника та політв'язня І. Геля, отримала цілком закономірний результат цього протистояння: «Режим програв боротьбу за людину. Homo soveticus уже не хотів слухати і дивитися пропагандистські агітки, а усіма можливими способами прагнув почути «ворожі голоси» із Заходу. Кількість їх щораз зростала, поліпшувалася якість технічного забезпечення мовлення, а розгалужена мережа глушилок на території СРСР хоч і розросталась, однак не могла заглушити подих свободи 3 вільного світу» [14: 68].

Діяльність Радянського Союзу в інформаційній сфері в період «холодної війни» давно стала синонімом заборон, цензури, а в радіоефірі - постійного глушіння «ворожих радіоголосів». На основі аналізу особливостей радіовійни, яку вів майже впродовж усього XX ст. СРСР з країнами Заходу, зокрема з українськими редакціями закордонних радіостанцій, вважаємо за потрібне виділити такі чотири етапи: 1) 30-ті роки - створення радіоперешкод мовленню закордонних радіостанцій, під яке потрапила українська редакція радіо «Ватикан»; 2) 50-ті роки - масове глушіння «ворожих радіоголосів» через початок «холодної війни»; 3) 70-80-ті роки - стрімке збільшення кількості станцій-радіоглушилок у зв'язку із зростанням дисидентського руху, передовсім в Україні; 4) 90-ті роки - припинення глушіння всіх без винятку програм закордонних радіостанцій падіння «залізної завіси» через розпад СРСР.

Отже, дослідження специфіки глушіння програм українських редакцій закордонних радіостанцій виявило, що радянська тоталітарна система, намагаючись протистояти надходженню інформації з вільного світу, незважаючи на колосальні фінансові витрати, не змогла отримати бажаного результату. Глушіння ефірів «ворожих радіоголосів» лише заохочувало українців до прослуховування програм, які доносили незалежну і правдиву інформацію про події у світі, Радянському Союзі та Україні зокрема. Програми українських редакцій закордонних радіостанцій стали одним із вагомих чинників, що пришвидшили розпад СРСР. Дослідження проблеми «глушіння» в контексті найрізноманітніших спроб контролю радянської тоталітарної системи над радіоефіром залишається актуальною темою для численних наукових студій, адже сучасні події засвідчують, що Росія, як правонаступниця СРСР, здійснює не менш жорсткі та репресивні заходи, для того щоб домогтися повного контролю над усіма медіа: телебаченням, радіо, пресою та інтернетом. У зв'язку з російською агресією проти України ця проблема набуває для нашої держави стратегічно важливого значення.

\section{REFERENCES}

1. Сервіс Р. Товариші. Комунізм: світова історія / Сервіс Роберт. - К. : Темпора, 2012. $-616 \mathrm{c}$.

2. Ремовська О. Говорить Радіо Свобода. Історія української редакції / Олена Ремовська. - К. : Вид. дім «Києво-Могилянська академія», 2014. - 163 с.

3. Крисенко Д. С. «Медійний фронт» «холодної війни» 1980 -х років / Д. С. Крисенко // Український інформаційний простір. - № 1. - 2013. - С. 56-62.

4. Доступно 3: http://tyzhden.ua/history/70601/printview - 24.10.18.

5. Доступно 3: http://zakon.rada.gov.ua/laws/show/995 015?lang=uk) - 24.10.18.

6. Доступно 3: https://www.radiosvoboda.org/a/921169.html - 24.10.18. 
7. Каганов Ю. О. «Ворожі голоси»: ідеологічне протистояння на радіохвилях у Радянській Україні (друга половина ХХ ст.) / Ю. О. Каганов // Наукові праці історичного факультету Запорізького національного університету. - Вип. XXXV. Запоріжжя, 2013. - С. 193-201.

8. Доступно 3: www.radiocenzura.tripod.com/text.htm -24.10 .18 .

9. Мащенко І. Міфи і реалії телерадіоефіру / Іван Мащенко. - К. : Видання ДП «Агентство ТРК», 2001. - 262 с.

10. Доступно 3: https://www.radiosvoboda.org/a/26580023.html - 24.10.18.

11. Доступно 3: http://avr.org.ua/index.php/ROZDILY RES?idUpCat $=1367 \& p c=50 \&$ sort $=$ $1 \& \mathrm{fd}=\mathrm{date} \& \mathrm{pv}=1-24.10 .18$.

12. Ісаїв X. Переговори на захист прав людини і дисидентів в епоху Совєтів. Спогади / Ісаїв Христина; пер. $з$ англ. Українська всесвітня правозахисна асоціація. - К. : Гамазин, 2016. - 328 с.

13. Саттер Д. Доба безумства. Занепад і кінець Радянського Союзу / Девід Саттер ; пер. $з$ англ. Наталії Комарової. - К. : ДУХ І ЛІТЕРА, 2017. - 528 с.

14. Гель I. Виклик системі: український визвольний рух другої половини XX століття / ред. та упор. І. В. Єзерська; Центр досліджень визвольного руху. - Львів : Часопис, 2013. - 392 с., іл. 


\title{
JAMMING THE PROGRAMS OF UKRAINIAN EDITORIAL OFFICE OF FOREIGN RADIO STATIONS DURING THE COLD WAR
}

\author{
Ivan Tsyperdiuk \\ Private institution of higher education «King Danylo University», \\ 35 Yevhena Konovaltsia, 76000, Ivano-Frankivsk, Ukraine \\ e-mail: ivandjuk@ukr.net
}

The study analyzed the specifics of jamming the programs of Ukrainian editorial offices of foreign radio stations, the amount of money invested in this direction, as well as the reasons for the special attention of the Soviet ideologists to foreign radio broadcasting in Ukraine. It was found out that according to the plan the Soviet Union started to use jamming as the main element of confrontation in the radio space on the eve of the Second World War, in particular, began to jam the programs of the Ukrainian editorial office of Vatican Radio.

The radio war by the Soviet Union was a logical consequence of the extraordinary efforts to establish a total control over the distribution of independent information. The listeners strove to get acquainted with the thoughts, which were alternative to the official position of the Soviet state regarding events in the USSR and abroad. This was also facilitated by the fact that foreign radio stations, as it is supposed for mass media, reacted instantly to current events.

Special attention of the Soviet ideologists was paid to Ukraine because of liberation struggles and numerous revolts of the 20-30s, the UPA struggle during the Second World War and post-war time, the movement of the sixties, the largest number of the Ukrainian political prisoners in camps and prisons. Broadcasting programs of the Ukrainian editorial offices of foreign radio stations in this context were perceived as completely hostile, targeted at strengthening the position of dissidents in the USSR, establishing the link between human rights defenders and the free world.

The Soviet Union allocated enormous funds for jamming the programs of the radio stations Radio Liberty, Voice of America, BBC, Deutsche Welle and others. However, despite the incredible financial expenses, the Soviet ideologists failed to stop the flow of the information that was distributed by the radio stations of the free world.

Jamming of the broadcasts of the «hostile radio voices» only encouraged Ukrainians to listen to the programs that provided independent and truthful news. The programs of the Ukrainian editorial offices of foreign radio stations have become one of the important factors that accelerated the collapse of the Soviet Union.

Key words: Cold War, jamming, dissidents, the Ukrainian editorial offices of foreign radio stations. 